\title{
ECOFLUSH - WASTEWATER RECYCLING AND RAINWATER HARVESTING TOILET FLUSH SYSTEM
}

\begin{tabular}{|l|l|l|}
\hline Mukesh Kumar Roy & Ayush Goyal & Vivek Kumar \\
MAE, ASET & ECE, ASET & MAE, ASET \\
Amity University Uttar Pradesh & Amity University Uttar Pradesh & Amity University Uttar Pradesh \\
$\begin{array}{l}\text { Noida, U.P., India } \\
\text { mukesh.roy@ student.amity.edu }\end{array}$ & Noida, U.P., India & Noida, U.P., India \\
agoyal1@ @amity.edu & vkumar7@amity.edu \\
\hline
\end{tabular}

\begin{abstract}
This research work proposes a household wastewater recycling and rainwater harvesting toilet flush system. This approach is economical and prevents the wastage of water at household or domestic level. By recycling wastewater this system avoids the waste of potable water and conserves energy used for pumping groundwater with boring submersibles and purification and filtration of water by municipal corporations or governmental agencies. Furthermore, the collection of rainwater provides an additional source of water for the flush. The recycled wastewater and harvested rainwater will be stored in a tank, which will be regularly treated with chlorine so as to ensure no bacterial growth. The tank storing the recycled wastewater will be connected to the toilet's flush. This Ecoflush toilet system will save approximately $\mathbf{7 3 0 0 0}$ litres of fresh potable government supply water or groundwater per annum and approximately 200 units of electricity per annum for an average household of 4-5 members.
\end{abstract}

Keywords-wastewater recycling; rainwater harvesting; energy conservation; toilet flush system; ecoflush

\section{INTRODUCTION}

Water is one of the most basic essential needs in our daily life routine. Its scarcity in our life is the biggest fear and thus various methods and systems are developed for its storage and conservation. Reusing rain water and water wasted in domestic purposes is one of the biggest challenges. It is one of the utmost requirements to save this water and recycle it so that it can be used again for different purposes.

Previous research on recycling of water for toilet flushing has been published on a method for processing and re-using of gray water for the flushing of toilets, particularly in vacuum toilet systems used in aircraft to optimize the use of available water. A method for processing and reusing gray water for flushing a toilet, comprising the following steps: a) filtering said gray water to provide filtered water, b) collecting said filtered water in a processing tank, c) anodically oxidizing said filtered water in said processing tank to provide processed water, and d) using said processed water for flushing a toilet bowl in a lavatory or toilet [1].

Other previous work relates to a system for the treatment of aircraft toilet waste water to permit discharge of the treated water to the atmosphere during flight, utilizing the pressure differential that is created between the aircraft's cabin pressure and the external atmosphere. The system includes a filter to remove suspended solids and other contaminants from the waste water, and may also include means to purify the water to potable water standards and means to recirculate the treated water for reuse on the aircraft [2]

A third publication in this area describes a water saving device of a flush valve type toilet bowl to economize on water by controlling the quantity of washing water according to urine or feces. The water saving device of a flush valve type toilet bowl comprises: a housing having a space inward; a sensor-cum-controller attached to a space of an upper cap of the housing to sense a user, to distinguish urine or feces automatically after stool and to drain the corresponding washing water [3].

A fourth area of research in this field relates to infraredbased monitoring signals providing a free water-saving toilet tank control device. The device includes an infrared sensing device with valve control structure; input of the microcontroller I / $\mathrm{O}$ with the infrared transmitter and receiver connected to the output, the output of the microcontroller I / O and control motor in series is connected to the water pipe of the pulse switch to perform the opening and closing structure; the switch actuator comprises two sets of switches which are respectively connected to output ends of the coil of the pulse motor [4].

A fifth paper on economical toilet flushing delineates a toilet stool flushing apparatus having two flush water channels, for carrying out pattern-dependent flushing and flushing a toilet stool such that the quantity of flush water is switched between stool flushing and urine flushing, wherein the toilet stool flushing apparatus is comprised of a human body detecting means which is set such that the length of a human body detecting duration correlates with the quantity of flush water, to thereby simplify the equipment and improve the operational ease thereof [5].

A sixth published work in the area of economical flushing relates to a control device of a pressure sensor of a seat toilet, which can be used for automatically distinguishing urine and stool so as to flush. The control device comprises a pressure sensor. The input end of a single-chip is connected with a flag bit of the pressure sensor. According to the time length of human pressure, the control device can automatically distinguish the urine and stool [6]. 


\section{(2) \\ ELK \\ Asia Pacific Journals}

Various systems are developed that recycle waste water from household and then use it in flush systems of toilets. These systems comprise two flush levels i.e. one for urine and one for stool. Flush water released is dependent on the duration of the user's stay time but a longer stay time does not always correspond to more stool or urine and thus it results in fresh potable water wastage.

Therefore, in view of the cited prior arts, there is a need to improve the flush system to save potable groundwater and government main supply plant-treated water from being wasted in toilet flushing.

Hence, the present work proposes a water-recycling, energy-conserving toilet flush system which collects water from rain harvesting and recycled shower, sink, kitchen, and laundry wastewater from the household's sewage drain pipe into a tank for flushing the toilet.

\section{METHODOLOGY}

\section{A. Wastewater Recycling and Rain Harvesting System}

The principal object of the proposed system is to provide an eco-friendly flush system that filters and collects recycled water from a household sewage drain pipe as well as rain harvesting system and uses it in toilet waste flushing to save potable groundwater and government main supply planttreated water from being wasted in toilet flushing.

Still another object of the proposed system is to provide an energy-saving environment-friendly flush system that reuses water from the kitchen, sink, shower, and washing machine.

Another object of the proposed system is to provide a flush system that uses rainwater harvesting as an additional source of water supply and thus reduces the demand of groundwater.

Yet another object of the proposed system is to provide a low installation and low running cost water-recycling toilet flush system that avoids expensive water purification as only simple membrane filtration is used for filtering the wastewater stored for toilet flushing.

Still another object of the proposed system is to provide a medicated storage of recycled water that automatically releases chlorine into the tank to prevent microbial growth.

\section{B. Proposed System Design}

The proposed system provides an eco-friendly toilet flush system that filters and stores recycled water from household use in a tank for toilet waste flushing to save potable groundwater and government main supply plant-treated water from being wasted in toilet flushing. The flush system collects water from rain harvesting and recycled shower, kitchen, and laundry wastewater sourced from the household's sewage drain pipe. The collected water is membrane-filtered and stored in a tank of approximately 200-litre or above capacity. The tank has a drainage pipe in case water exceeds the storage
ELK Asia Pacific Journals - Special Issue ISBN: 978-81-930411-4-7

level of the tank. Chlorine is released into the tank on a daily basis to prevent bacterial growth in the recycled water in the tank. The approach is environment friendly and provides an efficient way to reuse the wastewater at house hold level and saves energy required for pumping groundwater with a boring submersible and purification and filtration of main supply water by municipal corporations and government agencies.

\section{Proposed System Components}

In a preferred embodiment of the proposed system, the water-recycling, energy-conserving toilet flush system comprises a household waste water collection system from the household's sewage drain pipe; a rain water harvesting system; water recycling unit; and a storage tank.

\section{Proposed System Flowchart}

Figure 1 illustrates the design of our proposed wastewater recycling and rainwater harvesting toilet flush system.

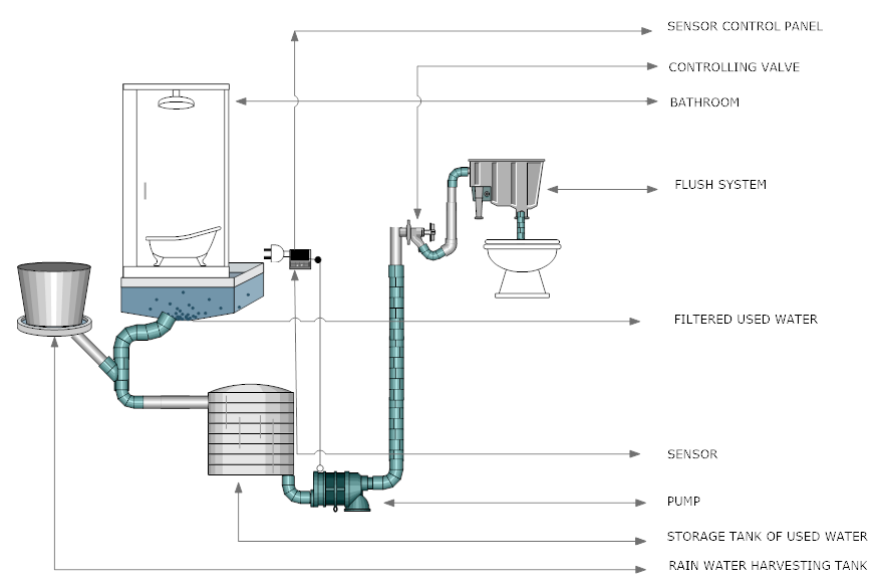

FIGURE 1: FLOWCHART OF THE WASTEWATER RECYCLING AND RAINWATER HARVESTING TOILET FLUSH SYSTEM

\section{RESULTS}

On average an Indian household of 4-5 members will require 20 flushes (given that each member requires approximately 4 flushes per day). Each flush is of approximately 10 litres of water, i.e., one household requires 200 litres of flush water per day. Table 1 presents the results of water and energy consumption for an average Indian household using the normal toilet flush and the eco-smart flush system proposed in this paper.

TABLE 1: NORMAL VERSUS ECOFLUSH WATER AND ENERGY CONSUMPTION FOR AN AVERAGE HOUSEHOLD

\begin{tabular}{|l|l|l|}
\hline Household & Potable water & Electric energy \\
\hline
\end{tabular}


ELK

\section{Asia Pacific Journals}

\begin{tabular}{|l|l|l|}
\hline Consumption & Consumed & Consumed \\
\hline $\begin{array}{l}\text { Normal } \\
\text { Toilet }\end{array}$ & $\begin{array}{c}\text { 200 litres / } \\
\text { day }\end{array}$ & $\begin{array}{l}\sim 22 \text { units / } \\
\text { month (for } \\
\text { daily usage of } \\
740 \text { watt pump } \\
\text { motor)* }\end{array}$ \\
\hline $\begin{array}{l}\text { Ecoflush } \\
\text { Toilet }\end{array}$ & $\begin{array}{l}\text { 0 litres / day } \\
\text { (since all } \\
\text { toilet flush } \\
\text { water is } \\
\text { household } \\
\text { recycled } \\
\text { wastewater } \\
\text { or harvested } \\
\text { rainwater) }\end{array}$ & $\begin{array}{l}\text { month (for } \\
\text { daily usage of } \\
\text { 370 watt pump } \\
\text { motor } \\
\text { connected to } \\
\text { recycled water } \\
\text { tank) }\end{array}$ \\
\hline
\end{tabular}

*740 WATT PUMP MOTOR IS USED AS AN EXAMPLE ONLY *DATA as Per BSES Website

\section{CONCLUSION}

As shown in Table 1, the normal toilet requires 200 litres of potable government supply water or groundwater whereas the Ecoflush saves this water since all the flush water in this proposed system is recycled household wastewater or harvested rainwater. Additionally, a normal household consumes 22 units of electricity per month for daily usage of a 740 watt pump motor to daily pump hundreds of litres of fresh potable government supply water for the day's use for toilet flushing. On the other hand, the Ecoflush system will only consume less than 5 units of electricity per month for daily usage of a 370 watt pump motor to pump the recycled wastewater from a storage tank into the toilet flush in the bathroom. Only a small 370 watt pump motor will suffice for the Ecoflush system because the head (vertical distance) to pump water is much less for the Ecoflush since the recycled wastewater storage tank will be in the house, whereas a large 740 watt pump motor is required in normal household systems because the head (vertical distance) to pump water is high since water is pumped from government supply pipes (or groundwater) to storage tanks on the roof. Thus the Ecoflush will save 200 litres of potable government supply water / day
ELK Asia Pacific Journals - Special Issue ISBN: 978-81-930411-4-7

and 17 units of electricity per month for an average Indian household. Table 2 presents these figures for annual consumption.

TABLE 2: ANNUAL WATER AND ENERGy CONSERVATION

\begin{tabular}{|l|l|l|}
\hline & Water Saved & Energy Saved \\
\hline $\begin{array}{l}\text { Ecoflush } \\
\text { Toilet }\end{array}$ & $\begin{array}{l}\sim 73000 \text { litres / } \\
\text { annum }\end{array}$ & $\begin{array}{l}\sim 204 \text { units / } \\
\text { annum }\end{array}$ \\
\hline
\end{tabular}

Furthermore, this household wastewater recycling system is supplemented by rainwater harvesting, which is a costeffective method for additional water gain in households.

In normal households, potable water provided by the government comes to the household pipes after it is treated by government plants. This precious potable water is wasted in toilet flushing. The Ecoflush wastewater recyling system will not only save this potable water but will also save energy and government funds and expenditure incurred by government plants that treat water for household consumption.

This Ecoflush water and electricity saving toilet system can be an integral part of any government funded housing development program, whether it be for construction or renovation of new or existing government quarters or government funded household schemes.

This Ecoflush wastewater recycling system will be an example of sustainable household water usage, which will save water and electricity for future generations to come.

\section{References}

[1] US Patent No. 7,118,677

[2] US Patent No. 6,143,185

[3] Patent Publication No. 20020066310

[4] Patent Publication No. 2876202

[5] Patent Publication No. 2001303649

[6] Patent Publication No. 201128939 